\title{
MENANAMKAN NILAI-NILAI ENTREPRENEURSHIP MELALUI PENDIDIKAN EKONOMI PADA ERA MASYARAKAT EKONOMI ASEAN
}

\author{
Waspodo Tjipto Subroto \\ Universitas Negeri Surabaya, Indonesia \\ Email: waspodotjipto@yahoo.co.id
}

\begin{abstract}
Abstrak: Menanamkan Nilai-Nilai Entrepreneurship Melalui Pendidikan Ekonomi pada Era Masyarakat Ekonomi ASEAN. Entrepreneurship memegang peranan yang dominan dalam menggerakkan roda perekonomian baik dalam skala lokal, regional maupun global. Para entrepreneur yang dinamis dan berkomitmen untuk sukses, terbukti mempengaruhi pertumbuhan ekonomi dan kesejahteraan. Entrepreneur yang memiliki semangat kepemimpinan dan jiwa entrepreneur ini akan memimpin revolusi ekonomi menuju peningkatan standar hidup yang lebih layak. Di tengahtengah liberalisasi Masyarakat Ekonomi ASEAN, nilai-nilai entrepreneurship, seperti kreativitas, inovatif, risiko moderat, ulet dan bertanggungjawab, optimistis, perlu selalu ditanamkan pada generasi muda, terutama melalui Pendidikan Ekonomi, sehingga jiwa dan semangat generasi muda dapat lebih kompetitif dalam menghadapi persaingan di era Masyarakat Ekonomi ASEAN. Peran Pendidikan Ekonomi sangat diperlukan untuk menyiapkan semangat generasi muda agar menjadi pelaku aktif dan partisipatoris dalam revolusi ekonomi menuju perubahan yang positif dan abadi.
\end{abstract}

Kata kunci: Entrepreneurship. Nilai dan sikap, Pendidikan Ekonomi.

\begin{abstract}
Instilling Entrepreneurship Values through Economic Education in the Era of the ASEAN Economic Community. Entrepreneurship has a dominant role to push economic activities at any level -- locally, regionally as well as globally. The dynamic entrepreneurs affect the economic growth and prosperity. Entrepreneurs who have a spirit of leadership and entrepreneurial spirit will lead the economic revolution to raise living standards. Under AEC the values of entrepreneurship, such as creative, innovative, tough, responsible, and optimistic, should always be instilled to the younger generation, especially through Economic Education. The Role of Economic Education is needed to prepare the young people to actively participate to positive economy activities.
\end{abstract}

Keywords: Entrepreneurship, Value, Economic Education

\section{PENDAHULUAN}

Dalam hal pendidikan entrepreneurship, Indonesia masih tertinggal dari Negaranegara lain. Beberapa Negara yang relatif maju kesejahteraannya, seperti Negaranegara Eropa dan Amerika Serikat, telah memulai pendidikan entrepreneurship pada perguruan tinggi sejak tahun 1970-an. Menurut Kasmir (2011) negara-negara maju telah menyadari lebih awal tentang pentingnya pendidikan entrepreneurship pada generasi muda. Demikian halnya sebagaimana yang dikampanyekan dalam pernyataan pada sidang Perserikatan BangsaBangsa bahwa suatu negara akan mampu membangun dengan efektif apabila memiliki entrepreneur sebanyak $2 \%$ dari jumlah penduduknya. Di Indonesia, idealnya ada sekitar 5 juta warga negara yang menekuni entrepreneurship. 
Jika negara Republik Indonesia ingin berhasil dalam pembangunan ekonominya, maka selayaknya menyediakan 5 juta entrepreneur besar dan sedang serta menciptakan 40 juta entrepreuneur kecil. Ini adalah suatu peluang besar yang menantang untuk berkreasi mengadu keterampilan membina entrepreneur dalam rangka turut berpartisipasi membangun negara dan bangsa Indonesia. KADIN sebagai lembaga yang berkewajiban mendorong tumbuhnya semangat entrepreneurship menargetkan pada tahun 2014 dapat tercipta 10 juta pengusaha baru. Sehingga diharapkan mampu menciptakan lapangan kerja baru. Contoh nyata peran serta entrepreneur dalam pembangunan adalah di negara Jepang. Keberhasilan pembangunan yang dicapai oleh negara Jepang ternyata disponsori oleh para entrepreneur yang jumlahnya cukup besar. Dahulu entrepreneurship merupakan bakat bawaan sejak lahir lalu diasah melalui pengalaman langsung di lapangan, tetapi sekarang ini paradigma tersebut telah bergeser. Entrepreneurship telah menjadi suatu disiplin ilmu yang mempelajari tentang nilai (value), kemampuan (ability) dan perilaku seseorang dalam menghadapi tantangan hidup untuk memperoleh peluang dengan berbagai risiko yang mungkin dihadapinya.

Teori-teori dalam pengembangan ekonomi memasukkan pendidikan entrepreneurship sebagai perangkat penting untuk pengembangan sektor usaha mikro dan kecil yang dominan. Di Indonesia Usaha Kecil dan Menengah berkontribusi terhadap 53,6 persen PDB nasional, dan member lapangan kerja lebih dari 91,8 juta orang. Banyak usaha yang tidak dapat berkembang karena antara lain kurangnya sumber daya manusia yang handal. Menumbuhkan semangat entrepreneurship di kalangan generasi muda tidak hanya akan berkontribusi untuk mengurangi pengangguran, tetapi juga dapat membantu mendorong produktivitas dan daya saing. Upaya untuk mengkonseptualisasikan pendidikan entrepreneurship, masih terus perlu dilakukan. Tetapi sampai saat ini belum muncul definisi yang disepakati bersama. Pendidikan entrepreneurship diartikan sebagai pembelajaran seumur hidup, sebagai proses pengembangan konsep dan keterampilan praktis untuk mengenali kesempatan, sumber-sumber daya utama dan upaya mengelola suatu usaha.

Pendidikan entrepreneurship memerlukan pergeseran paradigma dalam metodologi pembelajaran. Menurut Leonardos (2011) ada beberapa kasus di mana pelatihan individu-individu berpusat pada mahasiswa dan diikuti oleh dukungan coaching dan penghubungan ke sektor swasta, sehingga membawa dampak yang terlihat jelas, terutama terkait dengan: (a) pendekatan-pendekatan praktis, (b) jumlah mahasiswa yang mempertimbangkan untuk membuka usaha di masa yang akan datang, (c) jumlah mahasiswa yang dapat menghubungkan pembelajaran mereka sekarang dan pekerjaan mereka di masa yang akan datang. Kaum muda memerlukan bantuan dalam memformulasikan ide-ide bisnis, dorongan dan motivasi, sementara orang dewasa memerlukan lebih banyak bantuan yang terkait dengan pengelolaan bisnis. Selain itu penanaman nilai dan jiwa entrepreneurship masih sangat perlu diupayakan untuk membina generasi muda 
agar tertarik untuk terjun dan menekuni profesi entrepreneur. Dengan upaya ini diharapkan kualitas maupun kuantitas entrepreneur dari generasi muda dapat ditingkatkan secara bertahap menuju kuota yang ideal untuk mempercepat pembangunan ekonomi dan peningkatan kesejahteraan rakyat.

\section{PEMBAHASAN}

\section{Nilai-Nilai Entrepreneurship}

Nilai-nilai dasar yang penting untuk dipegang dan dijadikan dasar bagi seorang entrepreneur antara lain: kreativitas, inovatif, berani menghadapi risiko, memiliki etika bisnis dan norma, serta semangat dan bertanggungjawab. Modal utama entrepreneur menurut Alma (2008) adalah kreativitas, keuletan dan semangat bekerja. Semangat pantang menyerah ini memandang kegagalan hanya keberhasilan yang tertunda dan mereka tahan banting. Entrepreneur yang kreatif memiliki perhitungan cermat, mempertimbangkan segala fakta, informasi dan data. Seorang entrepreneur mampu memadukan apa yang ada di dalam hati, pikiran dan kalkulasi bisnis. Kreativitas adalah kemampuan untuk membuat kombinasi-kombinasi baru atau melihat hubungan-hubungan baru antara unsur, data dan variabel yang sudah ada. Kreativitas merupakan kemampuan seseorang untuk melahirkan sesuatu yang baru, baik berupa gagasan atau karya nyata, yang relatif berbeda dengan apa yang telah ada sebelumnya.

Kreativitas dan inovasi, menurut Kao (1993) memiliki hubungan yang erat. Karena kreativitas artinya adalah kemampuan untuk memikirkan sesuatu yang baru dan berbeda, sedangkan inovasi merupakan kemampuan untuk melakukan, mengaplikasikan sesuatu yang berbeda. Dengan demikian, yang paling penting dalam entrepreneurship adalah kemampuan pengusaha untuk lebih kreatif dan memanfaatkan inovasi dalam kegiatan bisnisnya sehari-hari. Seorang pengusaha akan berhasil apabila ia selalu kreatif dan menggunakan kreativitasnya tersebut. Menurut Gwee (2007) untuk menghadapi persaingan yang semakin kompleks dalam persaingan ekonomi global, maka kreativitas menjadi sangat penting untuk menciptakan keunggulan kompetitif dan kelangsungan bisnis. Nilai-nilai dasar yang penting dalam entrepreneur antara lain: kreativitas, inovatif, berani menghadapi risiko, memiliki etika bisnis dan norma yang baik, serta bertanggungjawab dan memiliki disiplin diri.

Menurut Hisrich (2005) ada beberapa nilai (value) yang bersifat umum yang dapat diamati sebagai karakteristik keberhasilan dalam entrepreneurship, yaitu: (1) Keinginan menghasilkan superior produk, (2) Layanan berkualitas terhadap konsumen, (3) Fleksibel, (4) Kemampuan dalam manajemen, (5) Memiliki sopan santun dan beretika, dan (6) Sikap seorang entrepreneur perlu selalu berusaha untuk menciptakan peluang bisnis dengan membangkitkan keberanian dan rasa bebas menciptakan sesuatu.

Kreativitas dan inovasinya perlu dikembangkan untuk menciptakan peluang bisnis yang mendatangkan profit maupun benefit bagi dirinya maupun orang lian. Untuk membangkitkan kreativitas memerlukan suatu proses dengan langkahlangkah tertentu yaitu sebagai berikut: (1) $\begin{array}{lll}\text { Preparation, (2) Investigation, (3) } & \text { (4) Incubation, } \\ \text { Transformation, (5) }\end{array}$ 
Illumination, (6) Verification, (7) Implementation. Seorang entrepreneur, menurut Yuyus (2011) harus selalu menciptakan mimpi dan ide baru, jeli dalam memanfaatkan peluang, dan memanfaatkan potensi menjadi profit dan benefit secara efektif.

Sifat seorang entrepreneur harus berani mengambil risiko yang telah diperhitungkan agar hasil yang diperoleh lebih besar daripada kegagalan dan sangat bergairah menghadapi tantangan. Menurut Hoffman (1994) tantangan baru ada artinya bagi seorang entrepreneur apabila terdapat risiko yang dapat diperhitungkan, yaitu dengan kriteria berikut: (1) Apabila mempengaruhi tujuan usaha yang ingin dicapai, (2) berarti bagi diri pribadi entrepreneur, (2) Kemampuan untuk mengendalikan diri pribadi entrepreneur, dan (3) Adanya suatu perasaan dan kepuasan kemungkinan dalam mengelola usaha untuk berhasil dan gagal. Kriteria dari suatu risiko menurut Leonardos (2009) mengandung potensi kegagalan dan potensi keberhasilan sehingga dapat dikelompokkan dalam tiga kelompok, antara lain: (1) Kelompok risiko tinggi, (2) Kelompok risiko rendah, dan (3) Kelompok risiko sedang. Adapun ciri-ciri entrepreneur saling berkaitan dengan perilaku pengambil risiko antara lain: (1) Pengambilan risiko berkaitan dengan kreativitas dan inovasi yang merupakan bagian penting, (2) dalam mengubah ide menjadi realitas, (3) Pengambilan risiko berkaitan dengan kepercayaan pada diri sendiri, Pengetahuan realistik, dan (4) mengenai kemampuan yang dimiliki.

Para entrepreneur merupakan pengambil risiko yang telah diperhitungkan agar hasil yang diperoleh lebih besar daripada kegagalan dan sangat bergairah menghadapi tantangan. Adapun sikap dalam menghadapi risiko, antara lain: (1) penghindar risiko, (2) netral, dan (3) penggemar risiko. Dengan jiwa entrepreneurship maka ketakutan akan risiko, tantangan dan hambatan akan bisa di atasi, dan mempunyai motivasi untuk menghasilkan yang terbaik. Selain itu seorang entrepreneur juga harus memiliki kemampuan dalam berkomunikasi sehingga bisa menjalin hubungan dengan konsumen, kelompok lain maupun pemerintah. Masyarakat yang dari lahir bukan keturunan pengusaha, jika memutuskan menjadi entrepreneur maka akan bisa menjadi entrepreneur melalui pelatihan maupun pendidikan tentang entrepreneurship.

Etika dan norma dalam bisnis merupakan nilai dasar yang harus dipegang untuk menjamin keberlanjutan dalam kegiatan bisnis di bidang apapun. Etika bisnis merupakan landasan penting dan harus diperhatikan terutama untuk menciptakan dan melindungi reputasi (goodwill) usaha apapun bentuknya. Oleh sebab itu, menurut Zimmerer (2008), etika bisnis merupakan masalah yang sangat sensitif dan kompleks, karena membangun etika untuk mempertahankan reputasi lebih sukar ketimbang menghancurkannya.

Selain etika dan perilaku yang tidak kalah pentingnya dalam bisnis adalah norma etika. Menurut Zimmerer (2008) ada tiga tingkatan norma etika, yaitu: (1) hukum, (2) kebijakan dan prosedur organisasi, dan (3) moral sikap mental individual. Adapun prinsip-prinsip etika dan perilaku bisnis yang selayaknya menjadi landasan perilaku bagi entrepreneur, antara lain: (1) Kejujuran, (2) Integritas, (3) 
Memelihara janji, (4) Kesetiaan, (5) Kewajaran/keadilan, (6) Suka membantu orang lain, (7) Hormat kepada orang lain, (8) Kewarganegaraan yang bertanggung jawab, (9) Mengejar keunggulan, (10) Dapat dipertanggungjawabkan.

Sedangkan

cara-cara

untuk mempertahankan standard etika, menurut Kao (2011) dapat dilakukan dengan kegiatan sebagai berikut: (1) Menciptakan kepercayaan perusahaan, (2) Kembangkan kode etika, (3) Jalankan kode etik secara adil dan konsisten, (4) Lindungi hak perorangan, (5) Adakan pelatihan etika, (6) Lakukan audit etika secara periodic, (7) Pertahankan standar yang tinggi tentang tingkah laku, jangan hanya aturan, (8) Hindari contoh etika yang tercela setiap saat, (9) Ciptakan budaya yang menekankan komunikasi dua arah, (10) Libatkan karyawan dalam mempertahankan standar etika.

Semangat dan tanggung jawab, menurut Suryana (2011) merupakan nilai dasar yang juga harus ditumbuhkan setiap saat. Semangat ditandai dengan keuletan dan pantang menyerah serta tidak mudah putus asa untuk meraih tujuan. Sikap bersemangat selalu berupaya dan optimis dengan mengerahkan seluruh potensi dirinya untuk mewujudkan keinginannya. Selain bersemangat, seorang entrepreneur harus memiliki sikap bertanggung jawab. Sikap bertanggungjawab ini meliputi: (1) tanggung jawab terhadap lingkungan, (2) terhadap karyawan, (3) terhadap pelanggan, (4) terhadap investor, dan (5) terhadap masyarakat. Sikap semangat dan bertanggung jawab ini perlu dijaga dan dikembangkan dalam berbagai kegiatan usahanya.
Nilai-nilai dasar dalam entrepreneurship ini akan mendukung dan melestarikan usaha atau bisnis sehingga perlu dijadikan dasar bagi perilaku dan moralitas para entrepreneur untuk menjamin pertumbuhan dan perkembangan usaha dan bisnisnya.

\section{Pendidikan Ekonomi}

Pada umumnya, Visi Program Studi Pendidikan Ekonomi adalah "Menjadikan program studi yang unggul (excellent) yang peduli dalam pengembangan pendidikan ekonomi". Sedangkan misinya Program Studi Pendidikan ekonomi, antara lain sebagai berikut: (1) Menyelenggarakan kegiatan pendidikan dalam rangka meningkatkan kualitas sumberdaya manusia, (2) Menyelenggarakan kegiatan pembelajaran dalam pendidikan ekonomi, (3) Mengembangkan kegiatan pengembangan kurikulum dalam pendidikan ekonomi, dan (4) Menyelenggarakan kegiatan penelitian dan pengabdian pada masyarakat dalam bidang pendidikan ekonomi (BELMAWA, 2013).

Program Studi Pendidikan Ekonomi menetapkan deskripsi umum dan kerangka kompetensi lulusan program studinya yang mencakup komitmen, karakter, kepribadian, sikap dalam berkarya, etika, dan moral sebagai berikut: (1) Bertaqwa kepada Tuhan Yang Maha Esa; (2) Memiliki etika, dan kepribadian yang menyelesaikan tugasnya; (3) Berperan sebagai warga negara yang bangga dan cinta tanah air, serta mendukung perdamaian dunia; (4) Mampu bekerjasama dan menjunjung kepekaan sosial dan kepedulian yang tinggi terhadap masyarakat dan lingkungannya; (5) Menghargai keanekaragaman budaya, dan 
agama; (6) Menjunjung tinggi penegakan hukum dan semangat mendahulukan kepentingan bangsa serta masyarakat luas di atas kepentingan pribadi.

Adapun Standar Kompetensi Lulusan Pendidikan Ekonomi (S1) diharapkan memiliki kualifikasi kompetensi sesuai yang disyaratkan Kerangka Kualifikasi Nasional Indonesia (KKNI) sebagai berikut: (1) Mampu mengelola sumberdaya di bawah tanggung jawabnya, dan mengevaluasi secara komprehensif kerjanya dengan memanfaatkan dan mengelola ICT yang menghasilkan langkah-langkah pengembangan strategi organisasinya, (2) Mampu memecahkan permasalahan ICT dalam pengembangan keilmuannya dengan pendekatan monodisipliner, (3) Mampu melakukan riset dan mengambil keputusan strategis dengan akuntabilitas dan tanggung jawab atas semua aspek di bidang keahliannya. Agar lulusan memiliki kompetensi KKNI maka lulusan harus memiliki Standar Kompetensi Lulusan (SKL) yang sudah dirumuskan sebagai berikut: (1) Memiliki merancang tentang wawasan atau landasan kependidikan, peserta didik, proses pembelajaran dalam pendidikan ekonomi sebagai landasan pedagogic dalam melaksanakan pembelajaran ekonomi; (2) Memiliki kemampuan menerapkan dan mengevaluasi pembelajaran dan program pendidikan ekonomi; (3) Memiliki pemahaman yang mendalam tentang konsep-konsep, prinsip- prinsip dan metode pendidikan ekonomi, (4) Memiliki sikap objektif, kritis terhadap berbagai persoalan ekonomi dan pendidikan ekonomi.

Dalam kegiatannya Program Studi Pendidikan Ekonomi menyelenggarakan pendidikan akademik pada jenjang sarjana strata satu (S-1) dengan kepada deskripsi kualifikasi Sumber Daya Manusia (SDM) yang dirumuskan dalam Kerangka Kualifikasi Nasional Indonesia, kualifikasi lulusan Program Studi Pendidikan Ekonomi berada pada level 6. Deskripsi generik level 6 terdiri dari empat kompetensi, yaitu: (1) Menguasai konsep teoretis dan menerapkan konsep keilmuan ekonomi dan pendidikan ekonomi dalam melaksanakan tugas sebagai tenaga kependidikan bidang pengetahuan dan konsep teoretis bagian khusus dalam bidang pengetahuan tersebut secara mendalam, serta mampu memformulasikan penyelesaian masalah procedural, (2) Melakukan dan memanfaatkan ICT dalam bidang keahliannya dan beradaptasi terhadap situasi yang dihadapi dalam penyelesaian Pendidikan Ekonomi, (3) Tindakan mengambil keputusan strategis berdasarkan analisis penelitian, informasi dan data, dan memberikan petunjuk dalam memilih berbagai alternative solusi, (4) Bertanggung jawab pada pekerjaan sendiri, kemandirian dan dapat diberi tanggung jawab atas komitmen pencapaian hasil kerja dalam pembelajaran ekonomi .

Sedangkan yang menjadi capaian pembelajaran (learning outcome) Program Studi Pendidikan Ekonomi, secara umum adalah: (1) Mampu menguasai dan menerapkan konsep keilmuan ekonomi dan pendidikan ekonomi dalam melaksanakan tugas sebagai tenaga kependidikan, (2) Mampu mengembangkan bidang keilmuan pendidikan dan pendidikan ekonomi berbagai alternative metode, model, dan strategi pembelajaran sesuai dengan perkembangan ICT dalam pembelajaran 
ekonomi, (3) Mampu melaksanakan pembelajaran ekonomi dan penelitian mandiri terkait dengan dan/atau dalam lingkungan pekerjaannya sebagai bagian dari upaya untuk meningkatkan kualitas proses dan hasil secara terencana dan terpadu dalam pendidikan ekonomi, (4) Mampu memiliki komitmen untuk meningkatkan kompetensi profesional secara berkelanjutan dan menyelesaikan setiap tugas profesinya secara mandiri dalam pendidikan ekonomi. Kemudian secara khusus, capaian pembelajaran ekonomi yaitu: Mampu melaksanakan pembelajaran ekonomi dan penelitian mandiri terkait dengan lingkungan pekerjaannya sebagai bagian dari upaya untuk meningkatkan kualitas proses dan hasil secara terencana dan terpadu dalam pendidikan ekonomi.

Pendidikan ekonomi dikembangkan dari berbagai sumber teori, antara lain: (1) Statistika Deskriptif, (2) Statistika Inferensial, (3) Ekonometrika, (4) Matematika Ekonomi, (5) Perekonomian Indonesia

Kewirausahaan, (7) Akuntansi Keuangan Dasar, (8) Aplikasi Akuntansi Keuangan, (9) Micro Teaching, (10) Seminar Pendidikan Ekonomi, (11) Permodelan dan Komputasi Ekonomi, (12) Ekonomi Industri, (13) Manajemen Strategik, (14) Manajemen Koperasi, (15) Ekonomi Industri, (16) Pasar Modal dan Portofolio, (17) Pengembangan UMKM, (18) Bank dan lembaga keuangan lain, (19) Kebijakan Perdagangan Internasional, (20) Manajemen Pemasaran Koperasi, (21) Manajemen Keuangan Koperasi, (22) Lembaga Keuangan Islam, (23) Manajemen Koperasi, (24) KKN, (25) PPL, (26) Ekonomi Regional, (27) Skripsi, (28) Seminar
Ekonomi dan Bisnis, (29) Perencanaan Pembangunan, (30) Ekonomi Moneter Internasional, dan (31) Studi Kelayakan Bisnis.

Dalam pelaksanaan pembelajaran pada pendidikan ekonomi perlu dikembangkan secara optimal seluruh potensi yang ada pada diri mahasiswa. Potensi yang bersumber dari otak kiri maupun otak kanan perlu dikembangkan secara seimbang. Terutama untuk mengoptimalkan potensi otak sebelah kanan yang dapat mendorong kreativitas dan inovasi seseorang. Otak sebelah kanan ini bersifat unconventional, unsystematic, unstructured yang sangat potensial untuk mengembangkan kreativitas dan inovasi mahasiswa.

\section{Penanaman Nilai-Nilai Entrepreneurship melalui Pendidikan Ekonomi}

Revolusi ekonomi terus bergulir merambah ke berbagai sendi kehidupan untuk menuju perbaikan dan kelayakan hidup. Para pembuat kebijakan telah menyadari pentingnya peran kaum entrepreneur dalam mewujudkan pertumbuhan ekonomi untuk menciptakan kesejahteraan ekonomi masyarakat. Entrepreneurship memegang peranan yang dominan dalam menggerakkan roda perekonomian baik dalam skala lokal, regional maupun global. Menurut Zimmerer (2008) para entrepreneur yang dinamis dan berkomitmen untuk sukses, terbukti mempengaruhi pertumbuhan ekonomi dan kesejahteraan. Entrepreneur yang memiliki semangat kepemimpinan dan jiwa entrepreneur ini akan memimpin revolusi ekonomi menuju peningkatan standar hidup yang lebih layak. Di tengah-tengah liberalisasi Masyarakat Ekonomi ASEAN, menurut 
Frinces (2011) perlu ditanamkan nilai-nilai entrepreneurship, seperti: kreativitas, inovatif, risiko moderat, semangat pantang menyerah dan optimistis serta bertanggung jawab, pada generasi muda, terutama melalui Pendidikan Ekonomi, sehingga jiwa dan semangat generasi muda dapat lebih kompetitif dalam menghadapi persaingan di era Masyarakat Ekonomi ASEAN. Peran Pendidikan Ekonomi sangat diperlukan untuk menyiapkan semangat generasi muda agar menjadi pelaku aktif dan partisipatoris dalam revolusi ekonomi menuju perubahan yang positif dan abadi.

Sebagai suatu disiplin ilmu, maka ilmu keentrepreneuran dapat dipelajari dan diajarkan, sehingga setiap individu memiliki peluang untuk tampil sebagai seorang entrepreneur. Bahkan untuk menjadi entrepreneur sukses, memiliki bakat saja tidak cukup, tetapi juga harus memiliki pengetahuan segala aspek usaha yang akan ditekuninya. Tugas dari entrepreneur sangat banyak, antara lain tugas mengambil keputusan, kepemimpinan teknis, kepemimpinan organisatoris dan Untuk menanamkan nilai-nilai, sikap dan sifat entrepreneurship dalam pendidikan ekonomi perlu dikembangkan model-model pembelajaran ekonomi yang kreatif dan inovatif, antara lain: (1) Pembelajaran langsung (direct instruction), (2) Pembelajaran Kooperatif (cooperative learning), (3) Pembelajaran Berdasarkan Masalah (Problem Base Instruction), dan (4) Belajar Melalui Penemuan (inquiry).

Model Pembelajaran Langsung (Direct Instruction) banyak diilhami oleh teori belajar sosial yang sering disebut belajar melalui observasi. John Dollard dan Albert Bandura (dalam Rusman, 2007) meyakini bahwa sebagian besar manusia belajar melalui pengamatan secara selektif dan mengingat tingkah laku orang lain. Dasar pemikiran model pengajaran langsung ini adalah bahwa mahasiswa belajar dengan mengamati secara selektif, mengingat dan mennganalisisnya. Atas dasar pemikiran tersebut maka yang perlu dihindari adalah penyampaian pengetahuan yang terlalu kompleks. Secara umum, pengetahuan dapat dibedakan menjadi dua, yaitu: pengetahuan deklaratif dan pengetahuan prosedural. Pengetahuan deklaratif itu adalah pengetahuan tentang sesuatu. Sedangkan pengetahuan prosedural adalah pengetahuan tentang bagaimana melakukan sesuatu. Dalam menerapkan pengajaran langsung, pengetahuan yang disampaikan kepada mahasiswa perlu disederhanakan, baik pengetahuan deklaratif maupun prosedural.

Model Pembelajaran Kooperatif (Cooperative Learning) menurut John Dewey (dalam Rusman, 2007) kelas seharusnya merupakan cerminan masyarakat yang lebih besar. Maka kegiatan di kelas perlu memberi pengalaman kepada mahasiswa untuk bekerja secara berkelompok. Model pembelajaran kooperatif ini mengingatkan bahwa kerjasama dan bekerja dalam kelompok akan memberikan hasil yang lebih baik. Setting kelas dalam pembelajaran kooperatif, perlu memenuhi 3 kondisi, yaitu: (a) adanya kontak langsung, (b) sama-sama berperan serta dalam kerja kelompok, (c) adanya persetujuan antar anggota kelompok tentang setting kelas tersebut.

Model pembelajaran kooperatif ini cukup penting karena mahasiswa dapat belajar dengan cara bekerjasama dengan temannya. 
Anggota kelompok yang lebih mampu dapat menolong temannya yang kurang mampu. Setiap anggota kelompok tetap memberi sumbangan pada prestasi kelompok. Dan yang lebih penting semua anggota kelompok dapat bersosialisasi dengan anggota kelompok lainnya sehingga hal ini akan melatih keterampilan sosial mahasiswa dalam bermasyarakat.

Model Pembelajaran Berbasis Masalah (Problem Base Instruction), ini mempunyai ciri umum yaitu menyajikan kepada mahasiswa masalah autentik dan bermakna yang akan memberi kemudahan kepada mahasiswa untuk melakukan penyelidikan dan inkuiri. Sedangkan ciri khusus dalam model ini yaitu adanya pengajuan pertanyaan dan masalah, berfokus pada keterkaitan antar disiplin ilmu, penyelidikan autentik, menghasilkan produk/karya, dan adanya kerjasama. Masalah autentik adalah masalah yang terdapat dalam kehidupan sehari-hari dan bermanfaat secara langsung jika ditemukan penyelesaiannya. Sedangkan masalah akademik adalah masalah yang muncul akibat pengaruh dari suatu masalah sehingga memunculkan masalah lainnya. Misalnya bagaimanakah pengaruh kenaikan harga BBM terhadap harga-harga bahanbahan pokok?

Model pembelajaran melalui Penemuan (Inquiry) merupakan suatu model pengajaran yang menekankan pentingnya membantu mahasiswa memahami struktur atau ide kunci dari suatu disiplin ilmu, mahasiswa aktif terlibat dalam proses pembelajaran, dan memberi keyakinan bahwa pembelajaran akan terjadi melalui penemuan pribadi. Bruner (dalam Rusman, 2007) yang memelopori model pembelajaran penemuan ini meyakini bahwa model penemuan ini akan merangsang mahasiswa untuk melakukan penyelidikan sehingga menemukan sesuatu. Misalnya dosen menyajikan topik kepada mahasiswa tentang peristiwa-peristiwa yang memancing prokontra atau konflik kognitif, sehingga motivasi dan rasa ingin tahu mahasiswa terpancing. Model pembelajaran penemuan lebih cocok untuk menanamkan konsepkonsep yang dapat ditemukan melalui percobaan dan penyelidikan.

Dari berbagai model pembelajaran dalam menanamkan nilai dan sifat entrepreneurship dalam pendidikan ekonomi, perlu dipilih dan disesuaikan dengan karakteristik bahan pembelajaran dalam pendidikan ekonomi, sehingga guru dapat lebih profesional dalam menyiapkan mahasiswa untuk memasuki era Masyarakat Ekonomi ASEAN.

\section{SIMPULAN}

Dari pembahasan di atas dikemukakan beberapa simpulan antara lain:

1. Entrepreneurship memegang peranan yang dominan dalam menggerakkan roda perekonomian baik dalam skala lokal, regional maupun global. Para entrepreneur yang dinamis dan berkomitmen untuk sukses, terbukti mempengaruhi pertumbuhan ekonomi dan kesejahteraan. Entrepreneur yang memiliki semangat kepemimpinan dan jiwa entrepreneur ini akan memimpin revolusi ekonomi menuju peningkatan standar hidup yang lebih layak.

2. Untuk berpartisipasi aktif dalam era Masyarakat Ekonomi ASEAN, generasi muda perlu dibekali nilai-nilai entrepreneurship, seperti: kreativitas, 
inovatif, risiko moderat, bersemangat dan pantang menyerah serta optimistis dan bertanggung jawab, agar dapat berlaga dalam persaingan yang cukup ketat.

3. Pendidikan Ekonomi, merupakan salah satu media yang efektif untuk menanamkan nilai-nilai entrepreneurship pada generasi muda sehingga jiwa dan semangatnya dapat lebih kompetitif dalam menghadapi persaingan di era Masyarakat Ekonomi ASEAN. Peran Pendidikan Ekonomi sangat diperlukan untuk menyiapkan semangat generasi muda agar menjadi pelaku aktif dan partisipatoris dalam revolusi ekonomi menuju perubahan yang positif dan abadi.

\section{DAFTAR PUSTAKA}

Alma, Buchari, (2008) Keentrepreneuran Untuk Mahasiswa dan Umum. Bandung: Alfabeta.

BELMAWA. (2013) Deskripsi Umum Dan Learning Outcome 12 Prodi LPTK. Jakarta: Ditjen Dikti dan Asosiasi LPTK Indonesia (ALPTKI).

Frinces, Z Heflin. (2011) Be an Entrepreneur. Yogyakarta: Graha IImu.

Gwee, James. (2007) Positive Business Ideas: Proven, Practical and Easy-To Apply Ideas to Improve Your Performance. New York: Delmar Publisher.

Hisrich, Robert D., Michel P, Peter, Sherped Dean. (2005) Entrepreneurship. $6^{\text {th }}$ Edition. Boston: Mc Graw Hill.

Hoffman, Kenneth and Richard Russell. (1994) Exploring the World of the Entrepreneur Working for yourself. New York: Delmar Publisher.

Kao John J. (1993) Entrepreneurship Creativity and Organization: Tax, Cases and Reading. New York: McGraw Hill.

Kasmir. (2011) Kewirausahaan. Jakarta: PT Raja Grafindo Persada.

Rusman. (2007) Model-Model Pembelajaran. Mengembangkan Profesionalisme Guru. Jakarta: PT Raja Grafindo Persada.

Leonardos. (2009) Kewirausahaan. Teori, Praktek dan Kasus-kasus. Jakarta: Salemba Empat.

Suryana, Yuyus \& Kartib Bayu. (2010) Kewirausahaan. Pendekatan Karakteristik Entrepreneurwan Sukses. Jakarta: Prenada.

Suryana. (2011) Kewirausahaan. Pedoman Praktis. Kita dan Proses Menuju Sukses. Jakarta: Salemba Empat.

Zimmerer, TW \& Scarborough, NM. (2008) Essential of Entrepreneurship and Small Business Management, $5^{\text {th }}$ Edition. .New Jersey: Saddle River. 